\title{
PEMBERIAN KOLOSTRUM PERTAMA PADA BAYI BARU LAHIR DAN FAKTOR TERKAIT
}

\author{
Suci Rahmani Nurita \\ Program Studi Kebidanan STIKes Baiturrahim Jambi \\ Email: sucirahmani85@gmail.com
}

\begin{abstract}
Decreased use of breast milk 98\% causes neonatal mortality in the world. One of the factors influencing the decrease is lactation management which is closely related to the practice of early breastfeeding in the form of colostrum. Delay in the giving of colostrum in early birth has an impact on the success of exclusive breastfeeding. This research is observational with cross sectional approach, aims to find out the probability of giving initial colostrum and related factors. The population in this study were 61 postpartum mothers and newborns in 2 hospitals (TK III Reksodiwiryo Hospital and DR. Rasyidin Hospital) and 4 Independent Midwives Practice (BPM) in the Andalas, Ambacang and Belimbing Community Health Centre. Samples were obtained by consecutive sampling. Statistical test results showed that in the vaginally group more than half of the respondents $(42.9 \%)$ started giving colostrum $<1$ hour after birth while in the C-section born group most respondents (80.8\%) started giving colostrum 7-23 hours after birth. Factors not related to when colostrum was first given to newborns were maternal education $(p=0.654)$, occupation $(p=1,000)$, parity $(p=0.113)$ and infant sex $(p=0.781)$. Factors related to when colostrum was first given to newborns were birth method $(p=0,000)$ and infant birth weight $(p=0.004)$. In this study it can be concluded that the probability of the first time colostrum was given by postpartum mothers was slower than that proclaimed by the ministry of health (30 minutes to 1 hour after birth) which was influenced by the way of birth of the baby and the birth weight of the baby. It is expected that the role of health workers in the Early Breastfeeding Initiation (IMD) as soon as possible after birth.

Keywords: colostrum, neonatal, post-partum, time probability
\end{abstract}

\begin{abstract}
ABSTRAK
Penurunan penggunaan ASI merupakan penyebab 98 \& kematian neonatal di dunia. Salah satu faktor berpengaruh terhadap penurunan adalah manajemen laktasi yang tidak optimal yang erat kaitannya dengan praktek pemberian ASI secara dini berupa kolostrum. Keterlambatan pemberian kolostrum di awal kelahiran memberikan dampak terhadap keberhasilan menyusui secara eksklusif. Penelitian ini bersifat observasional dengan pendekatan cross sectional, bertujuan untuk mengetahui probabilitas pemberian kolostrum awal dan faktor-faktor yang berhubungan. Populasi dalam penelitian ini adalah $61 \mathrm{ibu}$ postpartum dan bayi baru lahir di 2 Rumah sakit (RS TK III Reksodiwiryo dan RSUD DR. Rasyidin) dan 4 Bidan Praktik Mandiri (BPM) di wilayah Puskesmas Andalas, Ambacang dan Belimbing Kota Padang. Sampel diperoleh secara consecutive sampling. Hasil uji statistik menunjukkan bahwa pada kelompok pervaginam lebih dari separuh responden $(42,9 \%)$ mulai memberikan kolostrum $<1$ jam setelah kelahiran sedangkan pada kelompok perabdominal sebagian besar responden $(80,8 \%)$ mulai memberikan kolostrum 7-23 jam setelah kelahiran. Faktor yang tidak berhubungan terhadap waktu pemberian kolostrum pertama kali pada bayi baru lahir adalah pendidikan ibu $(p=0,654)$, pekerjaan $(p=1,000)$, paritas $(p=0,113)$ dan jenis kelamin bayi $(p=0,781)$. Faktor yang berhubungan terhadap waktu pemberian kolostrum pertama kali pada bayi baru lahir adalah cara lahir $(p=0,000)$ dan berat badan lahir bayi $(p=0,004)$. Dari penelitian disimpulkan bahwa probabilitas waktu pemberian kolostrum pertama kali oleh ibu postpartum lebih lambat dari yang dicanangkan oleh kementerian kesehatan (30 menit sd 1 jam setelah kelahiran) dipengaruhi cara lahir dan berat badan lahir. Peran tenaga kesehatan penting memastikan ibu melakukan IMD.
\end{abstract}

Kata Kunci : bayi baru lahir, kolostrum, pasca-lahir, probabilitas waktu 


\section{PENDAHULUAN}

Kematian bayi masih menjadi indikator yang menentukan derajat kesehatan dimana terjadi 3 juta kematian bayi setiap tahunnya di dunia pada periode neonatal awal, 98\% kematian terjadi di negara berkembang ${ }^{1}$. Tahun 2014, estimasi Angka Kematian Bayi (AKB) di Indonesia mencapai 23 kematian per 1.000 kelahiran hidup ${ }^{2}$. Sebanyak $40 \%$ kematian bayi disebabkan oleh penyakit infeksi seperti diare dan Infeksi Saluran Pernapasan Akut (ISPA) ${ }^{3}$. Pada tahun 2014, terdapat jumlah kematian neonatal di Provinsi Sumatera Barat sebanyak 689 orang dengan kematian neonatal tertinggi di Kota Padang sebesar $11,03 \%$, Kecamatan Kuranji memiliki proporsi tertinggi yaitu $19,73 \%^{4}$

\section{United Nation Children's} Fund (UNICEF) menyatakan sebanyak 30.000 kematian bayi di Indonesia dapat dicegah melalui pemberian Air Susu Ibu (ASI). ASI merupakan makanan bayi berstandar emas yang pemberiannya dimulai dengan Inisiasi Menyusui Dini (IMD), pemberian kolostrum, ASI eksklusif hingga 6 bulan, MP-ASI setelah bayi 6 bulan dan tetap memberikan ASI sampai bayi berusia 2 tahun ${ }^{5}$. ASI terutama kolostrum melindungi neonatus terhadap serangan infeksi patogen. Mekanisme perlindungan utama meliputi glikosolidat pada ASI yang berfungsi sebagai mimetik reseptor terlarut yang menghambat pengikatan patogen pada permukaan sel mukosa, stimulasi kolonisasi probiotik di usus oleh mikrobiota yang menguntungkan, imunomodulasi dan sebagai substrat untuk produk fermentasi bakteri baik di usus ${ }^{6}$.

Kecenderungan pemberian kolostrum mengalami peningkatan dari 74,7\% (2010) menjadi 85,3\% (2013). Namun masih terdapat kecenderungan untuk membuang sebagian kolostrum (8,9\%) dan membuang semua kolostrum $(5,9 \%)$ 7. Sihadi melakukan indepth interview terhadap 10 orang ibu yang memiliki bayi dua tahun yang sudah tidak menyusui anaknya lagi, ketika ditanyakan apa yang dilakukan ibu sesaat setelah bayinya dilahirkan, hanya 2 dari $10 \mathrm{ibu}$ mengungkapkan bahwa setelah bayi dibersihkan lalu ibu diminta menyusui bayinya. Dari hasil analisis survival data, diperoleh informasi median waktu pemberian ASI pertama kali adalah 1,85 jam, artinya $50 \%$ bayi mendapatkan proses menyusu dini di saat 1,85 jam setelah kelahirannnya ${ }^{8}$.

Faktor yang berpengaruh signifikan terhadap keterlambatan pemberian kolostrum pertama kali adalah komplikasi yang dialami ibu pada saat kehamilan, status pekerjaan ibu, status berat badan lahir anak, umur kandungan pada saat bayi dilahirkan, jenis persalinan dan lamanya bayi dirawat setelah dilahirkan. Dari enam faktor yang berpengaruh, lima faktor terkait proses persalinan, kondisi bayi yang dilahirkan, dan berhubungan dengan tenaga kesehatan serta fasilitas kesehatan ${ }^{8}$.

Pemberian kolostrum sesegera mungkin untuk menghindarkan bayi dari kematian dan kesakitan sangat diperlukan. Kementerian Kesehatan sudah mewajibkan dalam 1 jam pertama setelah bayi dilahirkan 
harus diberi ASI, namun data tentang waktu sesungguhnya pemberian ASI pertama kali oleh ibu pasca kelahiran bayinya sangat minim ${ }^{8}$. Penelitian ini bertujuan untuk menganalisis probabilitas waktu pemberian kolostrum pertama pada bayi baru lahir dan faktor yang berhubungan.

\section{METODE PENELITIAN}

Penelitian ini merupakan penelitian observasional dengan rancangan cross sectional. Populasi penelitian adalah semua ibu postpartum dari kehamilan aterm yang memiliki dan menyusui bayinya berusia $\leq 4$ hari dengan berat badan lahir normal di BPM atau RB Wilayah Kerja Puskesmas Andalas, Belimbing dan Ambacang serta Instalasi Rawat Inap Kebidanan di RS TK III DR. Reksodiwiryo dan RSUD DR. Rasyidin. Sampel pada penelitian ini berjumlah $61 \mathrm{ibu}$ postpartum dan bayi baru lahir yang memenuhi kriteria inklusi dan ekslusi yang diambil secara consecutive sampling dari bulan Oktober 2017 sd Januari 2018 .

Ibu yang memenuhi syarat inklusi penelitian akan diambil sebagai subjek penelitian dan diberi penjelasan sebelum persetujuan tentang penelitian yang akan dilakukan. Penelitian dilapangan melibatkan bidan yang bertugas di BPM dan instalasi rawat inap kebidanan RS yang sebelumnya telah diberi penjelasan dan persamaan persepsi untuk memantau waktu pertama kali ibu memberikan kolostrum pada bayinya dan mengisi lembar ceklist yang sudah peneliti sediakan.
Data yang didapatkan dianalisis secara univariat dan bivariat. Sebelum melakukan analisis bivariat, dilakukan uji normalitas data pada data yang berskala rasio yaitu usia panjang badan bayi dan berat badan bayi.

\section{HASIL DAN PEMBAHASAN}

Uji normalitas data menggunakan uji KolmogorovSmirnov karena sampel berjumlah > 50. Dari hasil uji normalitas data didapatkan semua variabel numerik berdistribusi normal dengan $p>0,05$ yakni diantaranya usia responden, panjang badan bayi dan berat badan lahir bayi. Dalam penelitian ini ditemukan bahwa lebih dari separuh responden melahirkan secara pervaginam sebanyak 35 orang $(57,4 \%)$, sebagian besar responden berpendidikan SMA/sederajat sebanyak 43 orang $(70,5 \%)$, sebagian besar responden memiliki pekerjaan sebagai ibu rumah tangga sebanyak 53 orang $(86,9 \%)$, lebih dari separuh responden memiliki status paritas multigravida sebanyak 36 orang $(59 \%)$ dan lebih dari separuh responden melahirkan bayi dengan jenis kelamin laki-laki sebanyak 32 orang $(52,5 \%)$.

Rata-rata usia responden adalah 29,18 tahun $\pm 5,309$. Ratarata panjang badan bayi baru lahir adalah 47,77 $\mathrm{cm} \pm 1,454$ dan ratarata berat badan bayi baru lahir adalah 3149,18 gram \pm 419,374. Hasil penelitian ini sejalan dengan hasil penelitian Hayatiningsih \& Ambarwati (2012) yang menyatakan tingkat pendidikan dan status pekerjaan baik pada responden persalinan normal maupun responden persalinan SC adalah 
SMA dan Ibu Rumah Tangga. Namun untuk status paritas, responden persalinan normal dan persalinan SC terbanyak terdapat pada partus pertama (primigravida) ${ }^{9}$. Kesimpulan sejalan juga dikemukakan oleh Dina (2017), pada 70 ibu postpartum baik persalinan normal maupun persalinan SC didapati sebagian besar responden berstatus paritas multipara $(71,4 \%)$ dan berpendidikan tingkat menengah atas $(80 \%){ }^{10}$.

Pada penelitian ini didapatkan rerata usia responden adalah $29,18 \pm 5,309$ tahun. Faktor usia merupakan faktor predisposisi yang berhubungan dengan pengalaman melahirkan dan mengasuh bayi. Pengalaman memainkan peranan penting bagi seorang ibu untuk melakukan pemberian kolostrum. Pengalaman adalah sumber pengetahuan informal yang pemanfaatannya ditentukan oleh kemampuan seseorang melakukan refleksi atas dampak dari pengalamannya tersebut ${ }^{11}$.

Hasil penelitian ini juga sejalan dengan hasil penelitian Dina (2017) dimana sebagian besar ibu postpartum (normal \& SC) berusia $\leq$ 30 tahun $(52,9 \%)^{10}$. Kesimpulan sejalan juga dikemukakan oleh
Hayatiningsih \& Ambarwati (2012) yang menyatakan umur responden persalinan spontan terbanyak pada usia 20-25 tahun $(57,6 \%)$ sedangkan responden persalinan SC banyak pada umur 26-30 tahun $(36,4 \%)^{9}$.

Dapat dilihat bahwa kelompok pervaginam lebih dari separuh responden sebanyak 15 orang $(42,9 \%)$ mulai memberikan kolostrum $<1$ jam setelah kelahiran sedangkan pada kelompok perabdominal sebagian besar responden sebanyak 21 orang $(80,8 \%)$ mulai memberikan kolostrum 7-23 jam setelah kelahiran.

Hal ini sejalan dengan hasil penelitian Wanda \& Tarigan (2001) yang menemukan dari $78,7 \%$ responden yang memberikan kolostrum, 49,5\% diantaranya memberikan kolostrum awal pada rentang waktu 1-24 jam setelah kelahiran ${ }^{12}$. Sejalan dengan hal itu, Djaiman \& Sihadi (2015) menyatakan probabilitas waktu pemberian ASI pertama kali oleh ibu pasca persalinan adalah 1,85 jam. Waktu ini lebih lambat dari yang dicanangkan oleh kemenkes bahwa proses menyusui dini dimulai sebelum 30 menit sampai dengan 1 jam setelah kelahiran bayi ${ }^{8}$.

\section{Tabel 1 Distribusi Waktu Pemberian Kolostrum Pertama antara Kelompok Pervaginam dan Kelompok Perabdominal}

\begin{tabular}{lcccc}
\hline Waktu Pemberian & \multicolumn{5}{c}{ Kelompok Responden } \\
\cline { 2 - 5 } Kolostrum Pertama & $\mathrm{n}$ & $\%$ & $\mathrm{n}$ & $\%$ \\
\cline { 2 - 5 } & 15 & 42,9 & 0 & 0 \\
\cline { 2 - 5 } & 6 & 17,1 & 0 & 0 \\
\hline$<1$ jam kelahiran & 14 & 40 & 21 & 80,8 \\
\hline 1-6 jam kelahiran & & & & \\
\hline $7-23$ jam kelahiran & &
\end{tabular}




\begin{tabular}{|c|c|}
\hline 24-47 jam kelahiran & 19,2 \\
\hline Total & 100 \\
\hline Ada $6 \quad$ variabel $\quad$ yang & dilahirkan, cara persalinan dan \\
\hline $\begin{array}{l}\text { berpengaruh terhadap keterlambatan } \\
\text { pemberian ASI pertama kali oleh } \\
\text { seorang ibu kepada bayi, diantaranya }\end{array}$ & $\begin{array}{l}\text { lamanya bayi dirawat di rumah sakit } \\
8 \text {. Menurut Astuti (2015), variabel } \\
\text { yang berhubungan dengan praktik }\end{array}$ \\
\hline $\begin{array}{l}\text { komplikasi kehamilan, status } \\
\text { pekerjaan, berat badan bayi waktu } \\
\text { lahir, usia kehamilan sewaktu bayi }\end{array}$ & $\begin{array}{l}\text { pemberian kolostrum adalah } \\
\text { pengetahuan, paparan ASI kolostrum } \\
\text { dan dukungan bidan }{ }^{13} \text {. }\end{array}$ \\
\hline
\end{tabular}

Tabel 2 Distribusi frekuensi hubungan pendidikan ibu dengan waktu pemberian kolostrum pertama

\begin{tabular}{|c|c|c|c|c|c|c|c|c|}
\hline \multirow{3}{*}{ No } & \multirow{3}{*}{ Pendidikan } & \multicolumn{4}{|c|}{$\begin{array}{c}\text { Waktu Pemberian Kolostrum } \\
\text { Pertama }\end{array}$} & \multirow{2}{*}{\multicolumn{2}{|c|}{ Jumlah }} & \multirow{3}{*}{$\begin{array}{c}\text { P- } \\
\text { Value }\end{array}$} \\
\hline & & \multicolumn{2}{|c|}{$\begin{array}{c}>6 \text { jam } \\
\text { kelahiran }\end{array}$} & \multicolumn{2}{|c|}{$\begin{array}{l}</=6 \text { jam } \\
\text { kelahiran }\end{array}$} & & & \\
\hline & & $\mathrm{N}$ & $\%$ & $\mathrm{n}$ & $\%$ & $\mathrm{n}$ & $\%$ & \\
\hline 1 & SD-SLTA & 35 & 63,6 & 20 & 36,4 & 55 & 100 & \\
\hline 2 & $\begin{array}{l}\text { Diploma, } \\
\text { Sarjana dan } \\
\text { Pascasarjana }\end{array}$ & 5 & 83,3 & 1 & 16,7 & 6 & 100 & 0,654 \\
\hline & Total & 40 & 65,6 & 21 & 34,4 & 61 & 100 & \\
\hline
\end{tabular}

Berdasarkan tabel 2, dari total 61 responden, 55 responden yang memiliki tingkat pendidikan SDSLTA, sebanyak 35 orang $(63,6 \%)$ memberikan kolostrum pertama $>6$ jam kelahiran. Dari 6 responden yang memiliki tingkat pendidikan Diploma-Pascasarjana, sebanyak 5 responden $(83,3 \%)$ juga memberikan kolostrum pertama $>6$ jam kelahiran. Dari hasil uji statistik diperoleh $p$ value 0,654 ( $\mathrm{p}$-value > 0,05) yang berarti tidak terdapat hubungan bermakna antara tingkat pendidikan ibu dengan waktu pemberian kolostrum pertama pada bayi baru lahir. Hal ini sejalan dengan penelitian Djaiman \& Sihadi (2015), yang menemukan bahwa tingkat pendidikan ibu tidak termasuk dalam variabel yang berhubungan dengan waktu pemberian kolostrum ${ }^{8}$.

Faktor pendidikan dan pekerjaan merupakan faktor pemicu terjadinya pemberian ASI (kolostrum) kepada bayi. Pendidikan ibu yang lebih tinggi cenderung pengetahuan ibu juga semakin luas, namun perlu disertai niat yang kuat untuk memberi kolostrum 11. Berdasarkan tabel 3, dari total 61 responden, 53 responden yang tidak bekerja, sebanyak 35 orang $(66 \%)$ memberikan kolostrum pertama $>6$ jam kelahiran. Dari 8 responden yang bekerja, sebanyak 5 responden $(62,5 \%)$ juga memberikan kolostrum pertama > 6 jam kelahiran. Dari hasil uji statistik diperoleh p-value 1,000 (p-value > 0,05) yang berarti tidak terdapat hubungan bermakna antara 
pekerjaan ibu dengan waktu bayi baru lahir. pemberian kolostrum pertama pada

Tabel 3 Distribusi Frekuensi Hubungan Pekerjaan Ibu dengan Waktu Pemberian Kolostrum Pertama

\begin{tabular}{|c|c|c|c|c|c|c|c|c|}
\hline \multirow{3}{*}{ No } & \multirow{3}{*}{ Pekerjaan } & \multicolumn{4}{|c|}{$\begin{array}{c}\text { Waktu Pemberian Kolostrum } \\
\text { Pertama }\end{array}$} & \multirow{2}{*}{\multicolumn{2}{|c|}{ Jumlah }} & \multirow{3}{*}{ P-Value } \\
\hline & & \multicolumn{2}{|c|}{$\begin{array}{c}>6 \text { jam } \\
\text { kelahiran }\end{array}$} & \multicolumn{2}{|c|}{$\begin{array}{l}\leq 6 \text { jam } \\
\text { kelahiran }\end{array}$} & & & \\
\hline & & $\mathrm{n}$ & $\%$ & $\mathrm{~N}$ & $\%$ & $\mathrm{n}$ & $\%$ & \\
\hline 1 & Tidak Bekerja & 35 & 66 & 18 & 34 & 53 & 100 & \\
\hline \multirow[t]{2}{*}{2} & Bekerja & 5 & 62,5 & 3 & 37,5 & 8 & 100 & 1,000 \\
\hline & Total & 40 & 65,6 & 21 & 34,4 & 61 & 100 & \\
\hline
\end{tabular}

Hal ini berbeda dengan hasil penelitian Djaiman \& Sihadi (2015) yang menemukan bahwa seorang ibu yang bekerja mempunyai peluang kecil untuk memberikan ASI pertama kali diatas 1,85 jam dibanding ibu yang tidak bekerja ${ }^{8}$. Ibu yang bekerja akan mengalami kendala waktu dan tempat untuk proses menyusui yang maksimal kepada bayinya ${ }^{11}$.

Sementara dalam penelitian ini, baik ibu bekerja dan tidak bekerja, masing-masing sebagian besar responden memberikan kolostrum > 6 jam kelahiran, hal ini dipengaruhi oleh faktor-faktor lain.

Tabel 4 Distribusi Frekuensi Hubungan Paritas Ibu dengan Waktu Pemberian Kolostrum Pertama

\begin{tabular}{|c|c|c|c|c|c|c|c|c|}
\hline \multirow{3}{*}{ No } & \multirow{3}{*}{ Paritas } & \multicolumn{4}{|c|}{$\begin{array}{c}\text { Waktu Pemberian Kolostrum } \\
\text { Pertama }\end{array}$} & \multirow{2}{*}{\multicolumn{2}{|c|}{ Jumlah }} & \multirow{3}{*}{$\begin{array}{c}\mathrm{P}- \\
\text { Value }\end{array}$} \\
\hline & & \multicolumn{2}{|c|}{$\begin{array}{c}>6 \text { jam } \\
\text { kelahiran }\end{array}$} & \multicolumn{2}{|c|}{$\begin{array}{c}\leq 6 \text { jam } \\
\text { kelahiran }\end{array}$} & & & \\
\hline & & $\mathrm{n}$ & $\%$ & $\mathrm{n}$ & $\%$ & $\mathrm{n}$ & $\%$ & \\
\hline 1 & Primigravida & 13 & 52 & 12 & 48 & 25 & 100 & \\
\hline \multirow[t]{2}{*}{2} & Multigravida & 27 & 75 & 9 & 25 & 36 & 100 & 0,113 \\
\hline & Total & 40 & 65,6 & 21 & 34,4 & 61 & 100 & \\
\hline
\end{tabular}

Berdasarkan tabel 4 , dari total 61 responden, 25 responden yang berparitas primigravida, sebanyak 13 orang $(52 \%)$ memberikan kolostrum pertama $>6$ jam kelahiran. Dari 36 responden yang berstatus multigravida, sebanyak 27 responden (75\%) juga memberikan kolostrum pertama > 6 jam kelahiran. Dari hasil uji statistik diperoleh p-value 0,113 (p-value > 0,05) yang berarti tidak terdapat hubungan bermakna antara paritas ibu dengan waktu pemberian kolostrum pertama pada bayi baru lahir. Faktor paritas merupakan faktor pemungkin terjadinya pemberian ASI (kolostrum). Jumlah anak yang semakin banyak, jarak 
kelahiran yang semakin dekat akan mempengaruhi ibu untuk memberikan kolostrum ${ }^{11 .}$

Berdasarkan tabel 5, dari total 61 responden, 29 responden yang melahirkan bayi perempuan, sebanyak 18 orang (52\%) memberikan kolostrum pertama $>6$ jam kelahiran. Dari 32 responden yang melahirkan bayi laki-laki, sebanyak 22 responden $(68,8 \%)$ juga memberikan kolostrum pertama $>6$ jam kelahiran. Dari hasil uji statistik diperoleh $p$-value 0,781 (p-value > $0,05)$ yang berarti tidak terdapat hubungan bermakna antara jenis kelamin bayi yang dilahirkan dengan waktu pemberian kolostrum pertama pada bayi baru lahir

Tabel 5 Distribusi Frekuensi Hubungan Jenis Kelamin Bayi Baru Lahir dengan Waktu Pemberian Kolostrum Pertama

\begin{tabular}{|c|c|c|c|c|c|c|c|c|}
\hline \multirow{4}{*}{ No } & \multirow{4}{*}{$\begin{array}{c}\text { Jenis Kelamin } \\
\text { Bayi }\end{array}$} & \multicolumn{4}{|c|}{ Waktu Pemberian Kolostrum } & \multirow{3}{*}{\multicolumn{2}{|c|}{ Jumlah }} & \multirow{4}{*}{ P-Value } \\
\hline & & \multirow{2}{*}{\multicolumn{2}{|c|}{$\begin{array}{l}>6 \text { jam } \\
\text { kelahiran }\end{array}$}} & & & & & \\
\hline & & & & \multicolumn{2}{|c|}{$\begin{array}{l}</=6 \text { jam } \\
\text { kelahiran }\end{array}$} & & & \\
\hline & & $\mathrm{n}$ & $\%$ & $\mathrm{~N}$ & $\%$ & $\mathrm{n}$ & $\%$ & \\
\hline 1 & Perempuan & 18 & 62,1 & 11 & 37,9 & 29 & 100 & \multirow{3}{*}{0,781} \\
\hline \multirow[t]{2}{*}{2} & Laki-laki & 22 & 68,8 & 10 & 31,3 & 32 & 100 & \\
\hline & Total & 40 & 65,6 & 21 & 34,4 & 61 & 100 & \\
\hline
\end{tabular}

Tabel 6 Distribusi Frekuensi Hubungan Berat Badan Lahir Bayi dengan Waktu Pemberian Kolostrum Pertama

\begin{tabular}{|c|c|c|c|c|c|c|c|c|}
\hline \multirow{3}{*}{ No } & \multirow{3}{*}{$\begin{array}{l}\text { Berat Badan } \\
\text { Lahir Bayi }\end{array}$} & \multicolumn{4}{|c|}{$\begin{array}{l}\text { Waktu Pemberian } \\
\text { Kolostrum Pertama }\end{array}$} & \multirow{2}{*}{\multicolumn{2}{|c|}{ Jumlah }} & \multirow{3}{*}{ P-Value } \\
\hline & & \multicolumn{2}{|c|}{$\begin{array}{l}>6 \text { jam } \\
\text { kelahiran }\end{array}$} & \multicolumn{2}{|c|}{$\begin{array}{c}\leq 6 \text { jam } \\
\text { kelahiran }\end{array}$} & & & \\
\hline & & $\mathrm{n}$ & $\%$ & $\mathrm{n}$ & $\%$ & $\mathrm{n}$ & $\%$ & \\
\hline 1 & $2500-3000 \mathrm{gr}$ & 25 & 86,2 & 4 & 13,8 & 29 & 100 & \multirow{3}{*}{0,004} \\
\hline 2 & $>3000-3500 \mathrm{gr}$ & 9 & 42,9 & 12 & 57,1 & 21 & 100 & \\
\hline \multirow[t]{2}{*}{3} & $>3500-4000 \mathrm{gr}$ & 6 & 54,5 & 5 & 45,5 & 11 & 100 & \\
\hline & Total & 40 & 65,6 & 21 & 34,4 & 61 & 100 & \\
\hline $\begin{array}{l}\text { faktc } \\
\text { pem } \\
\text { anak } \\
\text { kelal } \\
\text { mem } \\
\text { mem } \\
\text { tabel } \\
\text { respe }\end{array}$ & $\begin{array}{l}\text { Faktor paritas } \\
\text { pemungkin } \\
\text { erian ASI (kolost } \\
\text { yang semakin } \\
\text { iran yang semaki } \\
\text { pengaruhi } \\
\text { oerikan kolostrum } \\
6 \text { dari total } 61 \\
\text { nden yang berat }\end{array}$ & $\begin{array}{l}\text { mer } \\
\text { ter } \\
\text { m). } \\
\text { nyak, } \\
\text { deka } \\
\text { Berda } \\
\text { pond }\end{array}$ & $\begin{array}{r}\text { kan } \\
\text { nya } \\
\text { llah } \\
\text { arak } \\
\text { kan } \\
\text { ituk } \\
\text { kan } \\
29 \\
\text { ahir }\end{array}$ & \multicolumn{5}{|c|}{$\begin{array}{l}\text { bayinya } 2500-3000 \text { gram, sebanyak } \\
25 \text { orang }(86,2 \%) \text { memberikan } \\
\text { kolostrum pertama }>6 \text { jam kelahiran. } \\
\text { Dari } 21 \text { responden yang berat badan } \\
\text { lahir bayinya }>3000-3500 \text { gram, } \\
\text { sebanyak } 12 \text { responden }(57,1 \%) \\
\text { memberikan kolostrum pertama }</= \\
6 \text { jam kelahiran. Dari } 11 \text { responden } \\
\text { yang berat badan lahir bayinya }\end{array}$} \\
\hline
\end{tabular}


$>3500-4000$ gram, sebanyak 6 responden (54,5\%) memberikan kolostrum pertama $>6$ jam kelahiran. Dari hasil uji statistik diperoleh $p$ value 0,004 ( $\mathrm{p}$-value $<0,05$ ) yang berarti terdapat hubungan bermakna antara berat badan lahir bayi dengan waktu pemberian kolostrum pertama pada bayi baru lahir.

Pada penelitian ini didapatkan rerata berat badan lahir bayi adalah $3149,18 \pm 419,374$ gram. Ada hubungan berat lahir bayi dengan volume kolostrum. Hal ini berkaitan dengan kekuatan untuk mengisap, frekuensi, dan lama penyusuan. Bayi berat lahir rendah (BBLR) mempunyai kemampuan mengisap kolostrum yang lebih rendah dibanding bayi yang berat lahir normal (lebih dari atau sama dengan 2500 gr) ${ }^{11}$. Hasil penelitian ini sejalan dengan hasil penelitian Saputra \& Lasmini (2016) pada 42 sampel bayi baru lahir baik pervaginam maupun perabdominal, $81 \%$ bayi memiliki berat lahir antara 2500-3499 gram $^{14}$.

Berdasarkan tabel 7, dari total 61 responden, 26 responden yang melahirkan secara perabdominal (SC), seluruhnya (100\%) memberikan kolostrum pertama $>6$ jam kelahiran. Dari 35 responden yang melahirkan secara pervaginam (normal), sebanyak 21 responden (60\%) memberikan kolostrum pertama $</=6$ jam kelahiran. Dari hasil uji statistik diperoleh $p$-value 0,000 (p-value $<0,05$ ) yang berarti terdapat hubungan bermakna antara cara kelahiran bayi dengan waktu pemberian kolostrum pertama pada bayi baru lahir.

Tabel 7 Distribusi Frekuensi Cara Lahir Bayi dengan Waktu Pemberian Kolostrum Pertama

\begin{tabular}{|c|c|c|c|c|c|c|c|c|}
\hline \multirow{3}{*}{ No } & \multirow{3}{*}{ Cara Lahir } & \multicolumn{4}{|c|}{$\begin{array}{c}\text { Waktu Pemberian Kolostrum } \\
\text { Pertama }\end{array}$} & \multirow{2}{*}{\multicolumn{2}{|c|}{ Jumlah }} & \multirow{3}{*}{$\begin{array}{c}\text { P- } \\
\text { Value }\end{array}$} \\
\hline & & \multicolumn{2}{|c|}{$\begin{array}{c}>6 \text { jam } \\
\text { kelahiran }\end{array}$} & \multicolumn{2}{|c|}{$\begin{array}{c}\leq 6 \text { jam } \\
\text { kelahiran }\end{array}$} & & & \\
\hline & & $\mathrm{n}$ & $\%$ & $\mathrm{n}$ & $\%$ & $\mathrm{~N}$ & $\%$ & \\
\hline 1 & Perabdominal & 26 & 100 & 0 & 0 & 26 & 100 & \multirow{3}{*}{0,000} \\
\hline \multirow[t]{2}{*}{2} & Pervaginam & 14 & 40 & 21 & 60 & 35 & 100 & \\
\hline & Total & 40 & 65,6 & 21 & 34,4 & 61 & 100 & \\
\hline \multicolumn{4}{|c|}{$\begin{array}{l}\text { Ibu dengan persalinan secara } \\
\text { perabdominal membutuhkan waktu } \\
\text { yang lebih lama dibandingkan ibu } \\
\text { postpartum pervaginam untuk mulai } \\
\text { memberikan kolostrum. Responden } \\
\text { dengan persalinan perabdominal } \\
\text { cenderung masih mengeluhkan sakit } \\
\text { pada daerah sayatan dan jahitan di } \\
\text { perut, sehingga ibu memilih untuk } \\
\text { istirahat dahulu dan memulihkan } \\
\text { kondisinya yang lemas sebelum } \\
\text { memberikan ASI awal pada bayinya } \\
9\end{array}$} & \multicolumn{5}{|c|}{$\begin{array}{l}\text { ibu juga berpengaruh terhadap } \\
\text { pengeluaran kolostrum dimana akan } \\
\text { berlangsung baik jika ibu merasa } \\
\text { rileks dan nyaman. Ketika ibu } \\
\text { mengalami stress, akan ada } \\
\text { pelepasan dari adrenalin (epinefrin) } \\
\text { yang dapat menyebabkan } \\
\text { vasokontriksi pembuluh darah alveoli } \\
\text { sehingga kadar oksitosin sedikit yang } \\
\text { dapat mencapai mioepitelium. Hal ini } \\
\text { menghambat pengeluaran kolostrum }\end{array}$} \\
\hline
\end{tabular}


Kunci utama keberhasilan pemberian ASI awal (kolostrum) terletak pada penolong persalinan. Dalam waktu 30 menit pertama setelah bayi lahir umumnya peran penolong persalinan sangatlah dominan. Bila ibu difasilitasi oleh penolong persalinan untuk segera memeluk bayinya, diharapkan interaksi antara ibu dan bayi segera terjadi yakni skin to skin dan Inisiasi Menyusu Dini (IMD) ${ }^{11}$.

Bayi baru lahir harus segera diletakkan pada dada ibu dan membiarkannya selama 30-60 menit dengan metode breast crawl, bukan untuk pemberian nutrisi tetapi untuk belajar menyusui guna mempersiapkan payudara ibu mulai memproduksi ASI. Perasaan senang melihat bayi dan kepuasan dapat menyusui akan merangsang kelenjar hipofise posterior mengeluarkan hormon oksitosin untuk mempercepat pengeluaran ASI. Selain itu gerakan untuk mengisap pada bayi baru lahir akan mencapai puncaknya pada waktu berusia 20-30 menit, sehingga apabila terlambat menyusui refleks ini akan berkurang dan melemah ${ }^{11}$.

\section{SIMPULAN}

Pada kelompok pervaginam lebih dari separuh responden $(42,9 \%)$ mulai memberikan kolostrum < 1 jam setelah kelahiran sedangkan pada kelompok perabdominal sebagian besar responden $(80,8 \%)$ mulai memberikan kolostrum 7-23 jam setelah kelahiran. Faktor yang berhubungan terhadap waktu pemberian kolostrum pertama kali pada bayi baru lahir diantaranya adalah cara lahir $(p$-value $=0,000)$ dan berat badan lahir bayi ( $p$ value $=0,004$ ).

SARAN

\begin{tabular}{lcr}
\multicolumn{2}{c}{ Disarankan $\quad$ bagi } & tenaga \\
kesehatan di & Rumah & Sakit, \\
hendaknya & memfasilitasi & ibu \\
postpartum & perabdominal & untuk \\
memberikan & kolostrum & sedini
\end{tabular}
mungkin kepada bayinya dan memotivasi ibu postpartum perabdominal untuk menyusui bayinya sesering mungkin. Disarankan bagi Bidan, hendaknya memberikan paparan promosi kolostrum mengenai manfaat kolostrum terhadap bayi pada saat melakukan antenatal care dan inisiasi menyusui dini. Hendaknya manajemen laktasi dimulai pada masa kehamilan agar tercapai keberhasilan menyusui pada ibu setelah melahirkan. Disarankan bagi ibu postpartum perabdominal hendaknya menyusui bayinya sesegera dan sesering mungkin.

\section{DAFTAR PUSTAKA}

1. Aldy, O.S., Lubis, B.M., Azlin, E., \& Tjipta, G.D. (2009). Dampak Proteksi Air Susu Ibu Terhadap Infeksi. Sari Pediatri. Vol. 11(3). pp.167-173.

2. Astuti, D. (2015). Praktik Pemberian Kolostrum Pada Bayi Baru Lahir di Kabupaten Kudus. Maternal. Vol. 12(1). pp.13-24

3. Dina, A.A., Sumarah, Kurniati, A. (2017). Hubungan Jenis Persalinan dengan Waktu Pengeluaran Kolostrum Pada Ibu Bersalin Kala IV di Kota Yogyakarta Tahun 2016. Jurnal Teknologi Kesehatan. Vol. 
13(1). pp. 33-37.

4. Dinas Kesehatan Kota Padang. (2015). Profil Kesehatan Kota Padang Tahun 2014. Padang: Dinas Kesehatan Kota Padang.

5. Djaiman, Sri P.H. \& Sihadi. (2015). Probabilitas Waktu Seorang Ibu Menyusui Pertama Kali Bayinya dan Faktor yang Mempengaruhi. Buletin Penelitian Kesehatan. Vol. 43(4). pp. 239-246.

6. Fikawati, $\mathrm{S} \&$ Syafiq, A. (2003). Hubungan Antara Menyusui Segera (Immediate Breastfeeding) dan Pemberian ASI eksklusif Sampai Dengan Empat Bulan. J Kedokteran Trisakti. Vol.22(2). pp.47-55.

7. Hayatiningsih, Nur \& Ambarwati, Winarsih Nur. (2012). Keluarnya Kolostrum Pada Ibu Post Partum di RSUD DR. Moewardi. Publikasi Ilmiah UMS. Vol. 5(2). pp.93-100.

8. Kementerian Kesehatan Republik Indonesia. (2014). Situasi dan Analisis ASI Eksklusif. Jakarta: Kementerian Kesehatan Republik Indonesia.

9. Kementerian Kesehatan Republik Indonesia. (2016).
Profil Kesehatan Indonesia Tahun 2015. Jakarta: Kementerian Kesehatan Republik Indonesia.

10. Liu, B. \& Newburg, DS. (2013). Human Milk Glycoproteins Protect Infants Against Human Pathogens. Breastfeeding Medicine. Vol. 8(4). pp.354-359.

11. Maryunani, A. (2012). Inisiasi Menyusu Dini, ASI Eksklusif dan Manajemen Laktasi. Jakarta: Trans Info Media.

12. Saputra, NPK \& Lasmini, PS. (2016). Pengaruh Inisiasi Menyusu Dini Terhadap Waktu Pengeluaran dan Perubahan Warna Mekonium serta Kejadian Ikterik Fisiologi. Jurnal Ilmu Kedokteran. Vol. 9(2). pp. 87-94.

13. Wanda, R.S., \& Tarigan, L.H. (2001). Pola pemberian ASI tiga hari pertama dan Faktor yang Berhubungan dengan Keluarnya ASI Pertama di Rumah Sakit Fatmawati Jakarta 1998. Sari Pediatri. Vol. 3(1). pp. 8-13.

14. World Health Organization. (2006). Neonatal and Perinatal Mortality . Switzerland : WHO Press. 